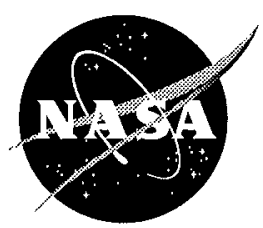

\title{
Measurement of Xenon Viscosity as a Function of Low Temperature and Pressure
}

Stanley P. Grisnik

Lewis Research Center, Cleveland, Ohio

Prepared for the

34th Joint Propulsion Conference

cosponsored by AIAA, ASME, SAE, and ASEE

Cleveland, Ohio, July 12-15, 1998

National Aeronautics and

Space Administration

Lewis Research Center

July 1998 
Available from

NASA Center for Aerospace Information 7121 Standard Drive

Hanover, MD 21076

Price Code: A03
National Technical Information Service 5287 Port Royal Road Springfield, VA 22100 Price Code: A03 


\title{
MEASUREMENT OF XENON VISCOSITY AS A FUNCTION OF LOW TEMPERATURE AND PRESSURE
}

\author{
Stanley P. Grisnik \\ National Aeronautics and Space Administration \\ Lewis Research Center \\ Cleveland, Ohio 44135
}

\begin{abstract}
$\underline{\text { Abstract }}$
The measurement of xenon gas viscosity at low temperatures (175 to $298 \mathrm{~K}$ ) and low pressures (350 to 760 torr) has been performed in support of Hall Thruster testing at NASA Lewis Research Center. The measurements were taken using the capillary flow technique. Viscosity measurements were repeatable to within 3 percent. The results in this paper are in agreement with data from Hanley and Childs and suggest that the data from Clarke and Smith is approximately 2 percent low. There are no noticeable pressure effects on xenon absolute viscosity for the pressure range from 350 to 760 torr.
\end{abstract}

\section{Introduction}

An interest in Russian electric propulsion technologies, specifically "Hall effect" thrusters, has increased due to their potential to increase the performance of Western spacecraft. Testing of these thrusters has been performed at NASA Lewis Research Center, to identify plume properties, performance limits, and component life limitations. ${ }^{1}$ Of interest is the Russian "thermal throttle," a capillary tube that uses resistive heating to vary the viscosity and density of the gas flowing through it and therefore throttle the mass flowrate. The thermal throttle operates at propellant pressures of 200 to 400 torr, and temperatures as low as $-90^{\circ} \mathrm{C}$ during cold soak testing. Difficulties with thermal throttle operation at the low temperatures and pressures seen in the NASA Lewis testing has prompted the need for xenon viscosity data. During the course of this work, limited sources of xenon viscosity data were identified. ${ }^{2,3}$ To remedy this situation, absolute viscosity measurements were made using a single capillary tube. The single capillary tube method introduces the possibility of additional errors in the viscosity values but due to the low pressure operation with no previous data available, an absolute viscosity value was needed. The dual capillary tube method eliminates the need for a mass flowrate measurement, and thus would have reduced the sources of error but would only furnish a relative viscosity value. In this paper all references to viscosity imply absolute viscosity.

Since the experimental apparatus was operated below atmospheric pressure, any leaks would change the gas composition and viscosity. The system was leak checked to $1 \times 10^{-9} \mathrm{~atm} \mathrm{cc} / \mathrm{sec}$ of helium using a Helium mass spectrometer to eliminate this possibility.

\section{Expermental Apparatus}

A schematic diagram of the flow system is shown in Fig. 1. It consists of a 2 liter high pressure xenon gas storage bottle, two stage gas pressure regulator, inlet flowcontroller, inlet pressure transducer, capillary tube, outlet pressure transducer, outlet flow controller, and vacuum pump.

The capillary tube was constructed of nominally $0.41 \mathrm{~mm}$ i.d. stainless steel tubing, $152 \mathrm{~cm}$ in length, wrapped on a $5.1 \mathrm{~cm}$ dia helix. The pressure transducers were capacitance manometer type, with an accuracy of 0.5 percent $F S$ for 0 to $101 \mathrm{kPa}$ operation. The mass flow controllers were 0 to $20 \mathrm{sccm}$, with an accuracy of 1 percent FS. The mass flow controllers showed a 2 to 3 percent change in flowrate reading during subatmospheric pressure operation. This was attributed to the change in heat transfer associated with the flow sensing element, as the pressure was lowered.

The capillary tube was immersed in an ethyl-alcohol/ $\mathrm{LN}_{2}$ bath. The bath was constructed of concentric cylinders with the annular space between the cylinders filled with glass beads and a heating element. The inner cylinder was filled with ethyl-alcohol and the cylinders were immersed in liquid nitrogen. The ethyl-alcohol was kept at the

Copyright $\odot 1998$ by the American Institute of Aeronautics and Astronautics, Inc. No copyright is asserted in the United States under Title 17, U.S. Code. The U.S. Government has a royalty-free license to exercise all rights under the copyright claimed herein for Governmental Purposes. All other rights are reserved by the copyright owner. 
desired temperature, within $\pm 1^{\circ} \mathrm{C}$, by on/off control of the heating element, using a PID (proportional, integral, derivative) controller with an RTD (resistance temperature detector) temperature sensor. The ethyl-alcohol was constantly stirred using an electric motor, to keep the temperature uniform.

The capillary tube's helical dimensions were chosen to reduce the "curved-pipe flow" pressure drop to a negligible value. This was accomplished by setting the Dean number to less than 7.0 as described by Dawe. ${ }^{4}$ The Dean number is described as follows:

$$
\mathrm{D}=(2 \mathrm{a} \rho v / \mu)(\mathrm{a} / \mathrm{R})^{1 / 2}
$$

where $a$ is the capillary tube radius, $R$ is the helix radius, $\rho$ is the gas density, $\mu$ is the viscosity, and $v$ is the gas velocity. ${ }^{5}$ The helical dimension was thus chosen to be $5.1 \mathrm{~cm}$.

\section{Procedure}

Before taking data, the valve between the capacitance manometers was opened and the system pressure was varied. Pressure readings between the two gages were compared to minimize any offset errors.

At ambient temperatures, the desired flowrate was set on the inlet flow controller. After the system was brought to the desired operating pressure (with the outlet flow controller "wide open"), the outlet flow controller was adjusted until the differential pressure across the capillary tube remained constant with respect to time. Data was then taken and the viscosity at ambient conditions was determined and compared to literature. The data set was repeated several times to establish the repeatability of the experimental hardware.

Finally, the ethyl-alcohol bath temperature was varied from ambient to $-100{ }^{\circ} \mathrm{C}$. At each temperature, the differential pressure was recorded for four different flowrates and three different operating pressures. The operating pressures were taken as the arithmetic average of the inlet and outlet pressures for each test point.

\section{Results and Discussion}

The capillary flow technique uses the Poiseulle formula for gases under low Reynold's number flow, and equates the pressure drop across a section of tubing to the viscosity of the gas, as follows:

$$
\mathrm{Q}=\frac{\pi \mathrm{r}^{4} p \Delta \mathrm{p}}{8 \mathrm{X} \mu}
$$

where $Q$ is mass flowrate, $r$ is the radius of the capillary tube, $\mu$ is viscosity, $X$ is the length of the capillary tube, $\rho$ is density of the gas, and $\Delta \mathrm{p}$ is the pressure drop in the capillary tube. ${ }^{6}$ The capillary tube inner diameter and length were determined by estimating the viscosity change that would be seen when the temperature of the gas was reduced from 300 to $190 \mathrm{~K}$. Then an acceptable gas flowrate was chosen, one that would give a measurable differential pressure at the two temperature extremes. The Reynolds number was checked to ensure laminar flow. This process was iterated until the proper capillary tube dimensions were obtained.

The capillary tube design was then checked to insured that the gas flowing inside the tube would reach equilibrium with the cold bath temperature. Hausen's equation for convective heat transfer in horizontal circular tubes was used (for Graetz numbers <100).

$\mathrm{Nu}=3.66+\left\{0.085 \mathrm{Gz} /\left(1+0.047 \mathrm{Gz}^{2 / 3}\right)\left(\mu_{\mathrm{b}} / \mu_{\mathrm{w}}\right)^{0.14}\right\}$

where Nu is the Nusselt number, Gz is the Graetz number, $\mu_{\mathrm{b}}$ and $\mu_{\mathrm{w}}$ is the viscosity evaluated at the bulk fluid temperature and wall temperature, respectively. ${ }^{7}$ The outlet temperature was estimated, a bulk viscosity was estimated, then a convective heat transfer coefficient was calculated. This value was used in a heat balance equation for the system:

$$
\mathrm{MCp}(\mathrm{To}-\mathrm{Ti})=\mathrm{hA}(\mathrm{Tb}-\mathrm{Ts})
$$

where $\mathrm{M}$ is mass flowrate, $\mathrm{Cp}$ is specific heat of xenon, $\mathrm{h}$ is convective heat transfer coefficient, $A$ is surface area of tube, To is outlet temperature, $\mathrm{Ti}$ is inlet temperature, $\mathrm{Ts}$ is surface temperature, and $\mathrm{Tb}$ is bulk fluid temperature $\{(\mathrm{To}+\mathrm{Ti}) / 2\}$. Simultaneously solving the heat balance and Hausen's equation for To and iterating until To estimated equals Tocalculated gives the outlet temperature expected for the capillary tube design. If the outlet temperature is not close enough to the desired outlet temperature, the capillary tube dimensions and/or mass flowrate needs to be changed and the entire process is repeated.

Corrections for the capillary tube dimensional changes with temperature were included. The equation used was:

$$
\mathrm{a}=\mathrm{a}_{0}(1+\alpha \Delta \mathrm{T})
$$

where $a_{0}$ is capillary radius at ambient conditions, $\alpha$ is the coefficient of thermal expansion for the capillary material, 
$\Delta \mathrm{T}$ is the temperature difference between ambient and the operating temperature. This correction was $<0.2$ percent.

Corrections for slip flow were examined. The correction is based on the equation:

$$
\mathrm{f}_{\mathrm{S}}=(1+4 \beta \lambda / \mathrm{a})
$$

where $\beta$ is equal to 1.147 as described by Dean, ${ }^{8} a$ is the radius of the capillary tube in $\mathrm{cm}, \lambda$ is the mean free path in $\mathrm{cm}$. Corrections for slip flow were examined and found to contribute less than 0.01 percent to the viscosity values and were therefore ignored.

Table I shows the data taken during testing along with the calculated viscosity values using Eq. (1). Figure 2 shows the viscosity vs. temperature data for atmospheric pressure measurements. The viscosity values vary from $152 \mu \mathrm{P}$ at $190 \mathrm{~K}$ to $229 \mu \mathrm{P}$ at $294 \mathrm{~K}$. A linear trend line through the data fits the equation:

$$
\mathrm{V}=(0.719) \mathrm{T}+17.2
$$

where $\mathrm{V}$ is viscosity in $\mu$ Poise, and $\mathrm{T}$ is temperature in Kelvin. Included on the graph is previously published data from Dawe/Smith ${ }^{9}$ and Hanley/Childs ${ }^{10}$ and Clarke/ Smith. ${ }^{11}$

The Data from Dawe, and Smith is for the 300 to $400 \mathrm{~K}$ temperature range. Extrapolating this data down to $190 \mathrm{~K}$ gives a viscosity valve of $151 \mu \mathrm{P}$, which is 0.6 percent lower than this papers measured value. The data from Clarke and Smith is for the 175 to $298 \mathrm{~K}$ temperature range. At $190 \mathrm{~K}$ Clarke and Smith measured a viscosity value of $149 \mu \mathrm{P}$, which is 2 percent lower than this papers measured value, and 1.3 percent lower than the values from Dawe and Smith. The data from Hanley and Childs is for the 100 to $180 \mathrm{~K}$ temperature range. Extrapolating this data to $190 \mathrm{~K}$ gives a viscosity value of $153 \mu \mathrm{P}$, which is 0.7 percent higher than this papers measured value.

\section{Conclusion}

The measurement of xenon gas viscosity at low temperatures (175 to $298 \mathrm{~K}$ ) and low pressures (350 to 760 torr) has been performed in support of the Hall Thruster testing at NASA Lewis Research Center. The measurements were taken using the capillary flow technique. Viscosity measurements were repeatable to within 3 percent. The results in this paper are in agreement with data from Hanley and Childs and suggest that the data from Clarke and Smith is approximately 2 percent low. There are no noticeable pressure effects on xenon absolute viscosity for the pressure range from 350 to 760 torr.

\section{$\underline{\text { References }}$}

1. Sankovic, J.M., Hamley, J.A., and Haag, T.W. "Performance Evaluation of the Russian SPT-100 Thruster at NASA LeRC," IEPC-93-094.

2. Clarke, A.G. and Smith, E.B., "Low-Temperature Viscosities of Argon, Krypton, and Xenon," The Journal of Chemical Physics, vol. 48 no. 9, May 1967.

3. Hanley, H.J.M., and Childs, G.E., "The Viscosity and Thermal Conductivity Coefficients of Dilute Neon, Krypton, and Xenon," NBS Technical Note 352, March 1967.

4. Dawe, R.A., Smith, E.B., "Viscosities of the Inert Gases at High Temperatures," The Journal of Chemical Physics, vol. 52, no. 2, Jan. 1970.

5. Dean, R.W., Phil. Mag. vol. 4, p. 208, 1927.

6. Rabinovich, V.A., Vasserman, A.A., Nedostup, V.I., Veksler,L.S., "Thermophysical Properties of Neon, Argon, Krypton, and Xenon," Hemisphere Publishing Corp. copyright 1988, p. 187.

7. Perry, R.H., Chilton, C.H., "Chemical Engineers' Handbook" Fifth Edition, McGraw-Hill Book Co. pp. 10-12 and 10-13.

8. Guevara,F.A., Mcinteer, B.B., Wageman, W.E., "High Temperature Viscosity Ratios for Hydrogen, Helium Argon and Nitrogen," The Physics of Fluids, vol. 12, no. 12 , Dec. 1969.

9. Dawe, R.A., Smith, E.B., "Viscosities of the Inert Gases at High Temperatures," The Journal of Chemical Physics, vol. 52, no. 2, Jan. 1970.

10. Hanley, H.J.M., and Childs, G.E., "The Viscosity and Thermal Conductivity Coefficients of Dilute Neon, Krypton, and Xenon," NBS Technical Note 352, March 1967.

11. Clarke, A.G. and Smith, E.B., "Low-Temperature Viscosities of Argon, Krypton, and Xenon," The Journal of Chemical Physics, vol. 48 no. 9, May 1967. 
TABLE I.-EXPERIMENTAL DATA

\begin{tabular}{|c|c|c|c|c|c|c|c|c|c|c|c|}
\hline $\begin{array}{c}\text { Flowrate, } \\
\text { sccm }\end{array}$ & $\begin{array}{l}\text { Upstream } \\
\text { press, } \\
\text { torr }\end{array}$ & $\begin{array}{c}\text { Downstream } \\
\text { press, } \\
\text { torr }\end{array}$ & $\begin{array}{l}\text { Operating } \\
\text { press, } \\
\text { torr }\end{array}$ & $\begin{array}{c}\text { Density, } \\
\mathrm{lb} / \mathrm{ft}^{3}\end{array}$ & $\begin{array}{c}\text { Gas vel. } \\
\mathrm{ft} / \mathrm{sec}\end{array}$ & $\begin{array}{l}\Delta \mathrm{P} \\
\mathrm{act}\end{array}$ & $\begin{array}{l}\text { Viscometer, } \\
\text { temperature }\end{array}$ & $\begin{array}{c}\text { Tube } \\
\text { diameter, } \\
\text { in. }\end{array}$ & $\begin{array}{c}\text { Tube area, } \\
\mathrm{ft}^{2}\end{array}$ & $\begin{array}{c}\text { Act. } \\
\text { visc., } \\
\mu P\end{array}$ & $\begin{array}{l}\mathrm{dp} \text {, } \\
\text { ref }\end{array}$ \\
\hline 5.9 & 775.7 & 753.2 & 764.5 & 0.48365 & 1.87526 & 22.5 & 210 & 0.01548 & $1.3071 \times 10^{-6}$ & 166 & 22.5 \\
\hline 4.94 & 773.7 & 754.9 & 764.3 & 0.48356 & 1.57044 & 18.8 & 210 & 0.01548 & $1.3071 \times 10^{-6}$ & $\overline{166}$ & 18.8 \\
\hline 7.94 & 778 & 748.1 & 763.1 & 0.48277 & 2.52829 & 29.9 & 210 & 0.01548 & $1.3071 \times 10^{6}$ & 164 & 29.9 \\
\hline 6.94 & 771.6 & 745.1 & 758.4 & 0.47980 & 2.22356 & 26.5 & 210 & 0.01548 & $1.3071 \times 10^{-6}$ & 165 & 26.5 \\
\hline 7.94 & 772.9 & 742.6 & 757.8 & 0.47942 & 2.54597 & 30.3 & 210 & 0.01548 & $1.3071 \times 10^{6}$ & 165 & 30.3 \\
\hline 4.94 & 767.3 & 748 & 757.7 & 0.47935 & 1.58423 & 19.3 & 210 & 0.01548 & $1.3071 \times 10^{-6}$ & 169 & 19.3 \\
\hline 8 & 753.4 & 692.4 & 722.9 & 0.32603 & 3.76271 & 61 & 295 & 0.01550 & $1.3104 \times 10^{6}$ & 225 & 61 \\
\hline 7.82 & 730.3 & 703.6 & 717.0 & 0.50135 & 2.39883 & 26.7 & 190 & 0.01548 & $1.3065 \times 10^{-6}$ & 154 & 26.7 \\
\hline 4.8 & 721.4 & 704.9 & 713.2 & 0.49869 & 1.48027 & 16.5 & 190 & 0.01548 & $1.3065 \times 10^{-6}$ & 155 & 16.5 \\
\hline 6.84 & 724.5 & 701.1 & 712.8 & 0.49845 & 2.11042 & 23.4 & 190 & 0.01548 & $1.3065 \times 10^{-6}$ & 154 & 23.4 \\
\hline 5.8 & 722.5 & 702.6 & 712.6 & 0.49827 & 1.79017 & 19.9 & 190 & 0.01548 & $1.3065 \times 10^{-6}$ & 154 & 19.9 \\
\hline 6.84 & 724 & 700.8 & 712.4 & 0.49817 & 2.11161 & 23.2 & 190 & 0.01548 & $1.3065 \times 10^{-6}$ & 152 & 23.2 \\
\hline 7.8 & 725.7 & 699 & 712.4 & 0.49813 & 2.40814 & 26.7 & 190 & 0.01548 & $1.3065 \times 10^{-6}$ & 154 & 26.7 \\
\hline 4.8 & 719.3 & 702.6 & 711.0 & 0.49715 & 1.48485 & 16.7 & 190 & 0.01548 & $1.3065 \times 10^{-6}$ & 156 & 16.7 \\
\hline 5.8 & 720.6 & 700.6 & 710.6 & 0.49691 & 1.79508 & 20 & 190 & 0.01548 & $1.3065 \times 10^{-6}$ & 154 & 20 \\
\hline 8 & 728.8 & 690.1 & 709.5 & 0.41342 & 2.97335 & 38.7 & 228 & 0.01548 & $1.3077 \times 10^{-6}$ & 181 & 38.7 \\
\hline 7 & 725.3 & 691.6 & 708.5 & 0.41284 & 2.60535 & 33.7 & 228 & 0.01548 & $1.3077 \times 10^{-6}$ & 180 & 33.7 \\
\hline 6 & 721.3 & 691.3 & 706.3 & 0.41159 & 2.23996 & 30 & 228 & 0.01548 & $1.3077 \times 10^{-6}$ & 186 & 30 \\
\hline 6 & 726.8 & 678.6 & 702.7 & 0.31691 & 2.90315 & 48.2 & 295 & 0.01550 & $1.3104 \times 10^{-6}$ & 231 & 48.2 \\
\hline 7 & 730.6 & 674.7 & 702.7 & 0.31689 & 3.38725 & 55.9 & 295 & 0.01550 & $1.3104 \times 10^{-6}$ & 229 & 55.9 \\
\hline 4.98 & 714 & 689 & 701.5 & 0.40879 & 1.87189 & 25 & 228 & 0.01548 & $1.3077 \times 10^{-6}$ & 185 & 25 \\
\hline 7.14 & 729.4 & 672.3 & 700.9 & 0.31247 & 3.50385 & 57.1 & 298 & 0.01550 & $1.3104 \times 10^{-6}$ & 227 & 57.1 \\
\hline 5.12 & 721.5 & 679.4 & 700.5 & 0.31230 & 2.51400 & 42.1 & 298 & 0.01550 & $1.3104 \times 10^{-6}$ & 233 & 42.1 \\
\hline 8.06 & 733.2 & 667.4 & 700.3 & 0.31223 & 3.95843 & 65.8 & 298 & 0.01550 & $1.3104 \times 10^{-6}$ & 231 & 65.8 \\
\hline 6.1 & 724.2 & 674.9 & 699.6 & 0.31189 & 2.99905 & 49.3 & 298 & 0.01550 & $1.3104 \times 10^{-6}$ & 229 & 49.3 \\
\hline 6 & 713.8 & 684 & 698.9 & 0.40727 & 2.26367 & 29.8 & 228 & 0.01548 & $1.3077 \times 10^{-6}$ & 183 & 29.8 \\
\hline 7 & 716.1 & 681.6 & 698.9 & 0.40724 & 2.64114 & 34.5 & 228 & 0.01548 & $1.3077 \times 10^{6}$ & 181 & 34.5 \\
\hline 5 & 711.2 & 686 & 698.6 & 0.40710 & 1.88721 & 25.2 & 228 & 0.01548 & $1.3077 \times 10^{-6}$ & 185 & 25.2 \\
\hline 8 & 718.3 & 678.6 & 698.5 & 0.40701 & 3.02018 & 39.7 & 228 & 0.01548 & $1.3077 \times 10^{-6}$ & 182 & 39.7 \\
\hline 5 & 716.4 & 675.8 & 696.1 & 0.31394 & 2.44223 & 40.6 & 295 & 0.01550 & $1.3104 \times 10^{-6}$ & 231 & 40.6 \\
\hline 5.04 & 716.3 & 674.1 & 695.2 & 0.30996 & 2.49341 & 42.2 & 298 & 0.01550 & $1.3104 \times 10^{6}$ & 235 & 42.2 \\
\hline
\end{tabular}




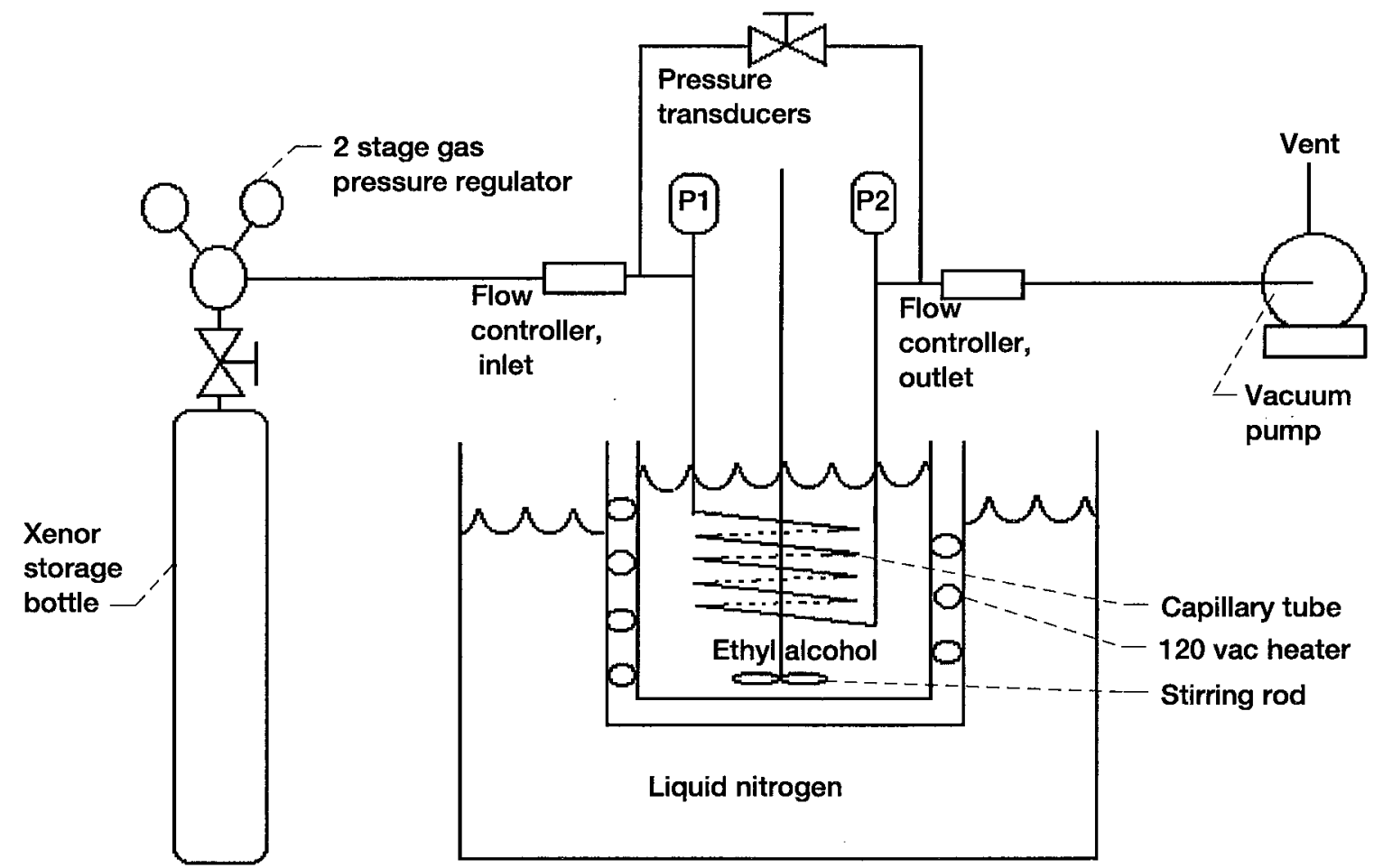

Figure 1.-Schematic diagram of experimental apparatus.

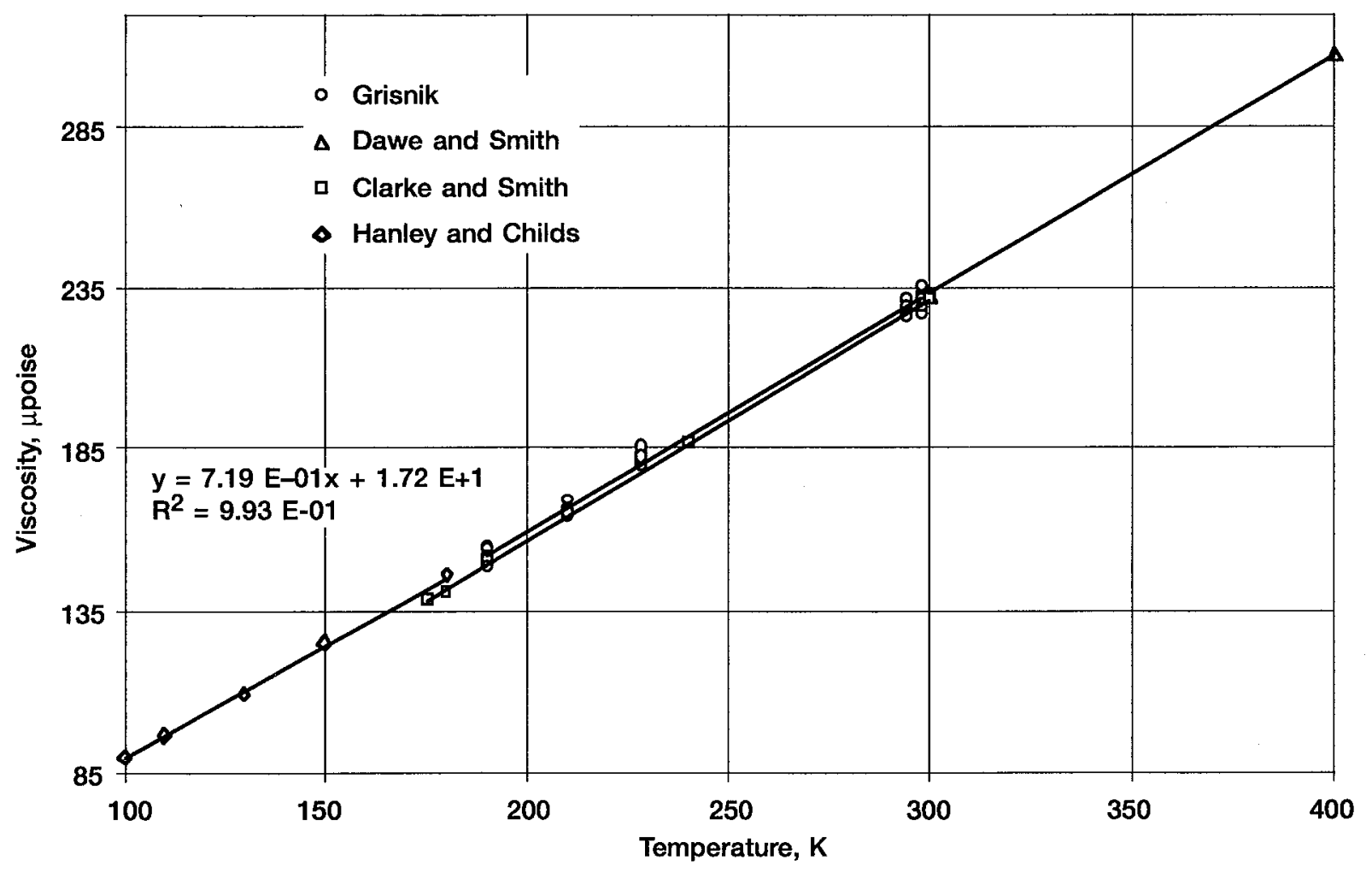

Figure 2.-Viscosity of gasous xenon vs temperature, 700-760 Torr. 


\section{REPORT DOCUMENTATION PAGE}

Public reporting burden for this collection of information is estimated to average 1 hour per response, including the time for reviewing instructions, searching existing data sources, gathering and maintaining the data needed, and completing and reviewing the collection of information. Send comments regarding this burden estimate or any other aspect of this collection of information, including suggestions for reducing this burden, to Washington Headquarters Services, Directorate for Information Operations and Reports, 1215 Jefferson Davis Highway, Suite 1204, Arlington, VA 22202-4302, and to the Office of Management and Budget, Paperwork Reduction Project (0704-0188), Washington, DC 20503.

\begin{tabular}{|l|c|c|}
\hline 1. AGENCY USE ONLY (Leave blank) & $\begin{array}{c}\text { 2. REPORT DATE } \\
\text { July } 1998\end{array}$ & $\begin{array}{r}\text { 3. REPORT TYPE AND DATES COVERED } \\
\text { Technical Memorandum }\end{array}$ \\
\hline 4. TITLE AND SUBTITLE & $\begin{array}{r}\text { 5. FUNDING NUMBERS } \\
\hline\end{array}$
\end{tabular}

Measurement of Xenon Viscosity as a Function of Low Temperature and Pressure

\section{AUTHOR(S)}

Stanley P. Grisnik

\section{PERFORMING ORGANIZATION NAME(S) AND ADDRESS(ES)}

National Aeronautics and Space Administration

Lewis Research Center

Cleveland, Ohio 44135-3191

9. SPONSORING/MONITORING AGENCY NAME(S) AND ADDRESS(ES)

National Aeronautics and Space Administration

Washington, DC 20546-0001

\section{SUPPLEMENTARY NOTES}

Prepared for the 34th Joint Propulsion Conference cosponsored by AIAA, ASME, SAE, and ASEE, Cleveland, Ohio, July 12-15, 1998. Responsible person, Stanley P. Grisnik, organization code 5430, (216) 977-7441.

\section{2a. DISTRIBUTION/AVAILABILITY STATEMENT}

Unclassified - Unlimited

Subject Categories: 20, 28, and 77

Distribution: Nonstandard

This publication is available from the NASA Center for AeroSpace Information, (301) 621-0390.
WU-632-1B-1B-00

8. PERFORMING ORGANIZATION REPORT NUMBER

E-11244

10. SPONSORING/MONITORING AGENCY REPORT NUMBER

NASA TM-1998-208409

AIAA-98-3498

ABSTRACT (Maximum 200 words)

The measurement of xenon gas viscosity at low temperatures (175-298K) and low pressures ( 350 torr -760 torr) has been performed in support of Hall Thruster testing at NASA Lewis Research Center. The measurements were taken using the capillary flow technique. Viscosity measurements were repeatable to within $3 \%$. The results in this paper are in agreement with data from Hanley and Childs and suggest that the data from Clarke and Smith is approximately $2 \%$ low. There are no noticeable pressure effects on xenon absolute viscosity for the pressure range from 350 torr to 760 torr.

\section{SUBJECT TERMS}

Thermodynamic properties; Electric propulsion

15. NUMBER OF PAGES

16. PRICE CODE

\section{1}

$\mathrm{A} 03$

\section{SECURITY CLASSIFICATION OF REPORT}

Unclassified

\section{SECURITY CLASSIFICATION OF THIS PAGE \\ Unclassified}

19. SECURITY CLASSIFICATION OF ABSTRACT Unclassified 